\title{
Virulence Genes, Antibiotic Resistance and Phylotyping of Escherichia coli 0157 Recovered from Diarrheic Calves
}

\author{
Noha M Bakry*, Walid S Awad and Samia A Ahmed \\ Department of Medicine and Infectious Diseases, Faculty of Veterinary Medicine, Cairo University, Giza, 12211, Egypt \\ *Corresponding author: noha_nady90@cu.edu.eg
}

\begin{tabular}{|c|c|c|}
\hline Article History: $20-152$ & Revised: 01-Sep-20 & Accepted: 04-Sep-20 \\
\hline \multicolumn{3}{|l|}{ ABSTRACT } \\
\hline $\begin{array}{l}\text { E. coli } \mathrm{O} 157 \text { is one of the } \\
\text { pathotype (AE-STEC). } \\
r f b E \mathrm{O} 157 \text { encoding gen } \\
\text { strains using multiplex P } \\
\text { respectively. The virulen } \\
\text { of these strains. All E. } \\
\text { amoxicillin/clavulanic a } \\
\text { gentamicin }(40 \%) \text {. Phen } \\
\text { strains were resistant to } \\
\text { extended spectrum } \beta \text {-lac } \\
\text { bla } \\
\text { genes revealed the role o }\end{array}$ & $\begin{array}{l}\text { food-borne pathogens that attributed to the attac } \\
\text { currence of E. coli O157 in diarrheic calves inve } \\
8.02 \% \text { within E. coli strains. Detection of AE- } \\
\text { owed the presence of eae, stx } 1 \text {, stx } x_{2} \text { and ehylA in } \\
\text { es profile of E. coli O157 revealed the predomin } \\
\text { O157 strains exhibited antibiotic multi-resistan } \\
\text { efalexin, cefuroxime and tetracycline, while t } \\
\text { resistance to extended spectrum cephalospori } \\
\text { xone and cefotaxime, while } 53.3 \% \text { were resistan } \\
\text { es (ESBLs) encoding genes recorded the superio } \\
\text { detected in percentages of } 40 \text { and } 20 \% \text {, respecti }\end{array}$ & $\begin{array}{l}\text { acing Shigatoxigenic } E \text {. coli } \\
\text { ough molecular detection of } \\
\text { lence genes in } E \text {. coli O157 } \\
\text { of } 93.3,73.3,20 \text { and } 13.3 \% \text {, } \\
+s t x_{I} \text { combination in } 66.7 \% \\
\text { igher resistance }(100 \%) \text { to } \\
\text { resistance was detected for } \\
\text { indicated that } 60 \% \text { of these } \\
\text { ome. Molecular detection of } \\
\text { EM gene }(100 \%) \text {, whereas the } \\
\text { enetic profiling of resistance } \\
\text { ination was detected only in } \\
\text { E. coli O157 strains. This } \\
\text { rains. }\end{array}$ \\
\hline
\end{tabular}

Key words: $E$. coli O157, Virulence \& Resistance genes, Diarrheic calves, Antimicrobial resistance, ESBLs.

@2020 IJVS - All Rights Reserved

\section{INTRODUCTION}

Escherichia coli $\mathrm{O} 157$ related to the attaching and effacing Shigatoxigenic E. coli (AE-STEC) pathotype, is considered one of the most significant food-borne pathogens associated with economic losses worldwide (Kamel et al. 2015; Thiry et al. 2017).

Infection of neonatal calves with AE-STEC O157 is characterized by diarrhea and hemorrhagic enteritis, while adult animals infected asymptomatically and act as a reservoir, the consumption of dairy and meat products contaminated with ruminant feces is linked to severe human infection characterized by bloody diarrhea, hemorrhagic colitis and hemolytic uremic syndrome (Mainil and Daube 2005; Stenkamp-Strahm et al. 2017).

AE-STEC virulence factors are attributed to the release of Shiga toxins (Stx1 and Stx2) (encoded by stx and $s t x_{2}$ genes), Intimin (Adhesin) protein (encoded by eae gene) that adheres bacteria to the intestinal villi forming attaching and effacing lesion and Enterohemolysin (encoded by ehylA gene) that enhances the effect of Shiga toxins and induces epithelial and endothelial cell damage (Naylor et al. 2005; Bielaszewska et al. 2014).

For antibiotic therapy of neonatal calf diarrhea, $\beta$ lactams, aminoglycosides, fluoroquinolones and tetracyclines, are frequently used (Constable 2004). This therapy is not preferred for AE-STEC $\mathrm{O} 157$ associated calf diarrhea, as the exposure to certain antibiotics may increase the severity of the disease due to the lysis of bacteria with the release of Shiga toxins (Mohsin et al. 2010; Saeedi et al. 2017).

Antibiotic multiple resistant AE-STEC O157 strains are of major concern, as they harbor several resistance genes that play a role in the spread of antibiotic resistance within various pathogenic and commensal E. coli (Srinivasan et al. 2007; Mehmood et al. 2020). Extended spectrum cephalosporin (ESC) resistant E. coli is the most important one and is mediated by the production of extended spectrum $\beta$ - lactamases (ESBLs) enzymes that confer resistance to penicillins, aminopenicillins, 3rd and 4th generation cephalosporins (Poirel et al. 2018; CDC

Cite This Article as: Bakry NM, Awad WS and Ahmed SA, 2021. Virulence genes, antibiotic resistance and phylotyping of Escherichia coli $\mathrm{O} 157$ recovered from diarrheic calves. International Journal of Veterinary Science 10(1): 1-7. https://doi.org/10.47278/journal.ijvs/2020.002 
2020). The treatment of ESC resistant $E$. coli is limited, as resistance genes encoding for other antibiotic classes, including fluoroquinolones, aminoglycosides, sulfonamides and trimethoprim, are carried on the same plasmid of ESBLs encoding genes (Hawkey and Jones 2009).

Phylotyping using PCR is considered a simple and rapid method for grading $E$. coli strains to one of the main phylogroups (A, B1, B2 and D) based on the presence or absence of three genetic markers (ChuA, YjaA and TspE4.C2) (Clermont et al. 2000).

This study aimed to investigate virulence genes profile, antibiotic resistance with the characterization of ESBLs encoding genes and phylotyping of AE-STEC O157 strains recovered from diarrheic calves in Egypt.

\section{MATERIALS AND METHODS}

\section{Animals and samples}

A total of 137 rectal swabs were collected from diarrheic calves up to 4 weeks old from different farms during the period from January 2019 to September 2019. Sterile cotton swabs were used for sampling, then inserted into the Amies transport medium (Oxoid, UK) and sent to the laboratory on the ice box.

\section{Bacteriological isolation and biochemical identification}

Fecal swabs were cultured on Tryptone Soya Broth (TSB) (Oxoid, UK) and incubated at $37^{\circ} \mathrm{C}$ for 18 hours. Subcultures were made on Eosin Methylene Blue (EMB) agar medium (Oxoid, UK) and incubated at $37^{\circ} \mathrm{C}$ for $24-48$ hours. Different colonies with a characteristic green metallic sheen were characterized as typical $E$. coli either O157 or non $\mathrm{O} 157$ strains and confirmed by biochemical identification according to Quinn et al (2002).

\section{Molecular identification of $\boldsymbol{E}$. coli $\mathbf{O 1 5 7}$}

The genomic DNA of all E. coli strains was extracted from overnight inoculated TSB using the boiling method as mentioned by Kang et al. (2004). The supernatant was used as a DNA template, stored at $-20^{\circ} \mathrm{C}$, for detection of gene encoding for the $\mathrm{O} 157$ somatic antigen $\left(r f b E_{\mathrm{O} 157}\right)$ using uniplex PCR (Table, 1).

For identification of $E$. coli O157, a uniplex PCR assay was applied in a $25 \mu \mathrm{l}$ mixture of DNA $(3 \mu \mathrm{l}), 2 \mathrm{X}$ Taq PCR Master Mix (Qiagen, Germany) (12.5 $\mu \mathrm{l}), r f b E_{\mathrm{O} 157}$ forward and reverse primers $(1 \mu \mathrm{l} \mathrm{each})$ and PCR grade water (Jena Bioscience, Germany) (7.5 $\mathrm{l})$. The amplification condition was applied according to Possé et al. (2007). E. coli serotype O157/H7 reference strain (ATCC $® 700927^{\mathrm{TM}}$ ) was used as a positive control for $r f b E_{\mathrm{O} 157}$ and other AESTEC virulence genes, whereas double distilled water was used as a negative control. PCR products were analyzed by agarose gel electrophoresis using 1.5\% agarose gel-stained with ethidium bromide, viewed under UV light and documented with a GelDoc 1000 fluorescent imaging system (Bio-Rad).

\section{Molecular detection of AE-STEC virulence genes}

All genomic DNA of the identified E. coli $\mathrm{O} 157$ strains were subsequently PCR tested for AE-STEC virulence genes ( st $_{1}$, stx $x_{2}$, eae and ehylA) using two multiplex PCR assays. The first PCR assay was used for the detection of eae and ehylA genes according to Chandra et al. (2013), whereas the second assay was applied for the detection of $s t x_{1}$ and $s t x_{2}$ genes according to Fagan et al. (1999). Target genes, oligonucleotide primer sequences and the expected product size in different PCR assays were mentioned in Table 1.

\section{Antimicrobial resistance test}

Antimicrobial resistance test was conducted on E. coli O157 strains using the Kirby-Bauer disk diffusion method (Bauer et al. 1966). The panel of these antibacterial agents consisted of $\beta$-lactams including, ampicillin (AMP, 10), amoxicillin/clavulanic acid (AMC, 30), cefalexin (CL, 30), cefuroxime (CXM, 30), ceftriaxone (CRO, 30), cefotaxime (CTX, 30), cefquinome (CFQ, 30) and cefoxitin (FOX, 30), and non $\beta$-lactams including, ciprofloxacin (CIP, 5), gentamicin (CN, 10), nalidixic acid (NA, 30), sulfamethoxazole/trimethoprim (SXT, 25) and tetracycline (TE, 30). Antibiotic disks were purchased from HiMedia, India, except for Cefquinome disks (Oxoid, UK). Antibiotic resistance results were interpreted according to CLSI (2013) and CLSI (2020).

\section{Determination of ESC resistant $E$. coli}

Strains of $E$. coli that confer resistance to one or more of third and fourth generation cephalosporins were considered ESC resistant E. coli according to CDC (2020).

\section{Molecular detection of ESBLs encoding resistance genes}

A multiplex PCR assay was conducted to detect ESBLs encoding genes $\left(\right.$ bla $_{T E M}$, bla $a_{S H V}$ and bla $\left._{\text {CTXM }}\right)$ using universal primers (Table, 1) according to Fang et al. (2008).

\section{Determination of $E$. coli phylogroups}

Phylogenetic groups of $E$. coli were determined using the Clermont phylotyping method based on the presence or absence of chuA, yjaA and TspE4.C2 genes combinations. For detection of these genes (Table, 1), a triplex PCR assay was conducted on E. coli $\mathrm{O} 157$ strains, which were allocated to one of the phylogroups A (chuA-/TspE4.C2-), B1 (chuA-/TspE4.C2+), B2 (chuA+/yjaA+) and D (chuA+/yjaA-) according to (Clermont et al. 2000).

\section{RESULTS AND DISCUSSION}

AE-STEC 0157 is regarded to be one of the causes of neonatal calf diarrhea and is perceived to be a serious human pathogen. A 187 E. coli strains were recovered from 137 diarrheic calves up to 4 weeks old relying on the selection of more than one strains from the same sample. Based on the detection of $r f b E O 157$ encoding gene using uniplex PCR (Fig. 1), 15 E. coli strains (8.02\%) were confirmed as E. coli $\mathrm{O} 157$. This is nearly agreed with Kang et al. (2004), Manna et al. (2006), and Kuyucuoğlu et al. (2011) who recovered E. coli O157 from diarrheic calves in percentages of $9.8 \%, 7.59 \%$ and $10.6 \%$, respectively. On the other hand, Stenkamp-Strahm et al. (2017) recovered $E$. coli $\mathrm{O} 157$ in a percentage of $0.25 \%$.

Genetic profiling of virulence markers was performed on 15 E. coli $\mathrm{O} 157$ strains using two multiplex PCR assays (Fig. 2 and 3). The virulence genes eae, stx 1 , stx 2 and ehlyA were detected in percentages of $93.3 \%, 73.3 \%, 20 \%$, and $13.3 \%$, respectively (Table, 2). The predominance of $s t x_{1}$ than $s t x_{2}$ was also detected by Mainil and Daube (2005). 
Int J Vet Sci, 2021, 10(1): 1-7.

Table 1: Primer names, target genes, oligonucleotide primer sequences and the expected product size used in different PCR assays Primer name (Target gene) $\quad$ Oligonucleotide primer sequences (5-3')

\begin{tabular}{|c|c|c|c|}
\hline \multicolumn{4}{|l|}{ E. coli $\mathrm{O} 157$ gene } \\
\hline $\mathrm{O} 157\left(r f b E_{\mathrm{O} 157}\right)$ & $\begin{array}{l}\text { CGG ACA TCC ATG TGA TAT GG } \\
\text { TTG CCT ATG TAC AGC TAA TCC }\end{array}$ & 259 & $\begin{array}{l}\text { Paton and Paton } \\
\text { (1998) }\end{array}$ \\
\hline \multicolumn{4}{|l|}{ AE-STEC virulence genes } \\
\hline $\mathrm{EAE}(e a e)$ & $\begin{array}{l}\text { TCA ATG CAG TTC CGT TAT CAG TT } \\
\text { GTA AAG TCC GTT ACC CCA ACC TG }\end{array}$ & 482 & Vidal et al. (2005) \\
\hline HlyA (ehlyA) & $\begin{array}{l}\text { AGC TGC AAG TGC GGG TCT G } \\
\text { TAC GGG TTA TGC CTG CAA GTT CAC }\end{array}$ & 569 & Wang et al. (2002) \\
\hline Stx $1\left(s t x_{1}\right)$ & $\begin{array}{l}\text { CGA TGT TAC GGT TTG TTA CTG TGA CAG C } \\
\text { AAT GCC ACG CTT CCC AGA ATT G }\end{array}$ & 244 & Müller et al. (2007) \\
\hline Stx2 $\left(s t x_{2}\right)$ & $\begin{array}{l}\text { CCA TGA CAA CGG ACA GCA GTT } \\
\text { CCT GTC AAC TGA GCA GCA CTT TG }\end{array}$ & 779 & Gannon et al. (1992) \\
\hline \multicolumn{4}{|l|}{ ESBLs encoding genes } \\
\hline SHV (blasHV) & $\begin{array}{l}\text { CTT TAT CGG CCC TCACTCAA } \\
\text { AGG TGC TCA TCA TGG GAA AG }\end{array}$ & 237 & Fang et al. (2004) \\
\hline TEM (bla $\left.{ }_{T E M}\right)$ & $\begin{array}{l}\text { CGC CGC ATA CAC TAT TCT CAG AAT GA } \\
\text { ACG CTC ACC GGC TCC AGA TTT AT }\end{array}$ & 445 & Monstein et al. (2007) \\
\hline СТX-M (bla & $\begin{array}{l}\text { ATG TGC AGY ACC AGTAAR GTK ATG GC } \\
\text { TGG GTR AAR TAR GTS ACC AGA AYC AGC GG }\end{array}$ & 593 & Boyd et al. (2004) \\
\hline \multicolumn{4}{|l|}{ Phylogroup encoding genes } \\
\hline ChuA $(c h u A)$ & $\begin{array}{l}\text { GAC GAA CCA ACG GTC AGG AT } \\
\text { TGC CGC CAG TAC CAA AGA CA }\end{array}$ & 279 & Clermont et al. (2000) \\
\hline $\mathrm{YjaA}(y j a A)$ & $\begin{array}{l}\text { TGA AGT GTC AGG AGA CGC TG } \\
\text { ATG GAG AAT GCG TTC CTC AAC }\end{array}$ & 211 & \\
\hline TspE4.C2 (TspE4.C2) & $\begin{array}{l}\text { GAG TAA TGT CGG GGC ATT CA } \\
\text { CGC GCC AAC AAA GTA TTA CG }\end{array}$ & 152 & \\
\hline
\end{tabular}

Table 2: Virulence genes profile of E. coli O157 strains

\begin{tabular}{|c|c|c|c|c|c|c|c|c|c|c|c|c|c|c|c|c|}
\hline Virulence genes; Strain. no & 1 & 2 & 3 & 4 & 5 & 6 & 7 & $8^{\mathbf{a}}$ & $9^{\mathbf{b}}$ & 10 & 11 & 12 & 13 & 14 & 15 & Total $(\%)$ \\
\hline eae & + & + & + & + & + & + & + & + & & + & + & + & + & + & + & $14(93.3)$ \\
\hline $\operatorname{stx}_{1}$ & + & + & + & + & + & & + & & & + & + & + & + & & + & $11(73.3)$ \\
\hline$s t x_{2}$ & & & & & & + & & & & & & & + & + & & $3(20)$ \\
\hline ehyla & & & & & & & & & & & & & + & + & & $2(13.3)$ \\
\hline$e a e+s t x_{1}$ & - & - & 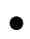 & 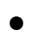 & - & & 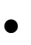 & & & $\bullet$ & $\bullet$ & $\bullet$ & & & & $10(66.7)$ \\
\hline$e a e+s t x_{2}$ & & & & & & - & & & & & & & & & & $1(6.7)$ \\
\hline$e a e+s t x_{2}+e h y l A$ & & & & & & & & & & & & & & $\bullet$ & & $1(6.7)$ \\
\hline$e a e+s t x_{1}+s t x_{2}+e h y l A$ & & & & & & & & & & & & & - & & & $1(6.7)$ \\
\hline
\end{tabular}

${ }^{\text {a }}$ Strain no. 8 carry eae gene only; ${ }^{\mathbf{b}}$ Strain no. 9 not carry any of the AE-STEC virulence genes.

Table 3: Antibacterial resistance testing, ESC resistance, ESBLs encoding genes profile and phylogroups of E. coli O157 strains

\begin{tabular}{|c|c|c|c|c|c|c|c|c|c|c|c|c|c|c|c|c|c|c|c|c|c|c|c|c|c|}
\hline \multirow{3}{*}{$\begin{array}{l}\text { Strain } \\
\text { no. }\end{array}$} & \multicolumn{13}{|c|}{ Antibacterial resistance testing } & ESC & \multicolumn{6}{|c|}{ ESBLs encoding genes } & \multicolumn{5}{|c|}{ Phylogroups } \\
\hline & \multirow[t]{2}{*}{$\overline{\mathrm{AMC}}$} & \multirow[t]{2}{*}{ CL } & \multirow{2}{*}{ CXM } & \multirow{2}{*}{$\mathrm{TE}$} & \multirow{2}{*}{ SXT } & \multirow{2}{*}{\multicolumn{2}{|c|}{ AMP FOX }} & \multirow[t]{2}{*}{ NA } & \multirow[t]{2}{*}{ CIP } & \multirow[t]{2}{*}{$\mathrm{CRO}$} & \multirow{2}{*}{ CTX } & \multirow{2}{*}{\multicolumn{2}{|c|}{ CFQ CN }} & \multirow{2}{*}{$\begin{array}{c}\text { resistance } \\
\text { Strain no. } \\
(\%)\end{array}$} & \multicolumn{6}{|c|}{ bla $_{\text {TEM }}$ bla $_{S H V}$ bla $a_{C T X M}$ Profile } & \multirow{2}{*}{\multicolumn{2}{|c|}{ A B1 }} & \multirow[t]{2}{*}{$\mathrm{B} 2$} & \multirow{2}{*}{\multicolumn{2}{|c|}{ D untypeable }} \\
\hline & & & & & & & & & & & & & & & & & & & 23 & 3 & & & & & \\
\hline 1 & + & + & + & + & + & + & + & + & + & + & + & + & + & Resistant & + & & & $\bullet$ & & & & & $\bullet$ & & \\
\hline 2 & + & + & + & + & + & + & + & + & + & + & + & + & + & $9(60)$ & + & + & + & & & $\bullet$ & & & $\bullet$ & & \\
\hline 3 & + & + & + & + & + & + & + & + & + & + & + & + & + & & + & & & $\bullet$ & & & & & $\bullet$ & & \\
\hline 4 & + & + & + & + & + & + & + & + & + & + & + & & + & & + & + & & & $\bullet$ & & & & $\bullet$ & & \\
\hline 5 & + & + & + & + & + & + & & + & + & + & + & + & + & & + & & & $\bullet$ & & & & & $\bullet$ & & \\
\hline 6 & + & + & + & + & + & + & + & + & + & + & + & + & & & + & & & $\bullet$ & & & & & & & $\bullet$ \\
\hline 7 & + & + & + & + & + & + & + & & & + & + & + & & & + & + & + & & & $\bullet$ & & & $\bullet$ & & \\
\hline 8 & + & + & + & + & + & + & + & & & + & + & + & & & + & + & & & $\bullet$ & & & & & $\bullet$ & \\
\hline 9 & + & + & + & + & + & + & + & & & + & + & + & & & + & + & + & & & $\bullet$ & & & $\bullet$ & & \\
\hline 10 & + & + & + & + & + & + & + & + & + & & & & + & Sensitive & + & & & $\bullet$ & & & & & $\bullet$ & & \\
\hline 11 & + & + & + & + & + & + & + & + & + & & & & & $6(40)$ & + & & & $\bullet$ & & & & & $\bullet$ & & \\
\hline 12 & + & + & + & + & + & & + & + & + & & & & & & + & & & $\bullet$ & & & & & $\bullet$ & & \\
\hline 13 & + & + & + & + & + & + & & + & + & & & & & & + & + & & & $\bullet$ & & & & $\bullet$ & & \\
\hline 14 & + & + & + & + & & & + & & & & & & & & + & & & • & & & & & $\bullet$ & & \\
\hline 15 & + & + & + & + & + & & & & & & & & & & + & & & $\bullet$ & & & & $\bullet$ & & & \\
\hline Total & 15 & 15 & 15 & 15 & 14 & 12 & 12 & 10 & 10 & 9 & 9 & 8 & 6 & & 15 & 6 & 3 & 93 & 33 & 3 & 0 & 1 & 12 & 1 & 1 \\
\hline$\%$ & 100 & 100 & 100 & 100 & 93.3 & 80 & 80 & 66.7 & 66.7 & 60 & 60 & 53.3 & 40 & & 100 & 40 & 20 & 602 & 202 & 20 & 0 & 6.7 & & 6.7 & 6.7 \\
\hline
\end{tabular}

ESBLs profile: $1=$ blaTEM, $2=$ bla $_{T E M}+$ bla SHV $_{\text {}}$ and $3=$ bla $_{T E M}+$ bla $_{S H V}+$ bla $_{\text {CTXM }}$.

The presence of eae gene in $93.3 \%$ of E. coli $\mathrm{O} 157$ strains is almost similar to that of Kang et al. (2004) who detected this gene in all E. coli $\mathrm{O} 157$ strains. This suggests the role of Intimin in the pathogenicity of E. coli O157 in calves and confirmed by Mainil and Daube (2005) who attributed the cause of diarrhea in calves and human infected with $E$. coli $\mathrm{O} 157$ to the attaching and effacing lesion caused by Intimin and not by the production of Shiga toxins.

The Enterohemolysin encoding gene (ehylA) was detected in $13.3 \%$ of the isolated strains, whereas Kang et al. (2004) and Kuyucuoğlu et al. (2011) detected this gene in $91.6 \%$ and $92.8 \%$ of E. coli $\mathrm{O} 157$ strains, respectively. 
Int J Vet Sci, 2021, 10(1): 1-7.

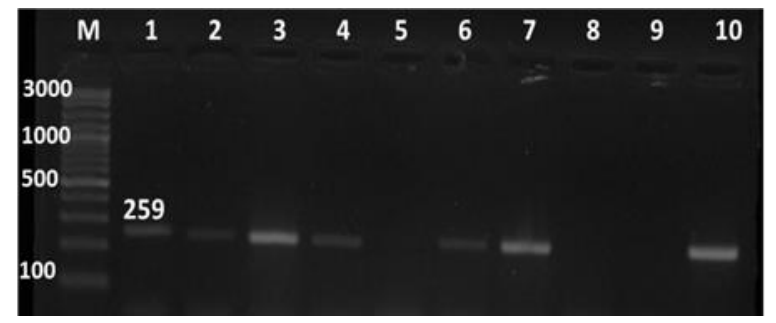

Fig. 1: PCR for detecting $r f b E_{0157}$ gene. Lane M: 100-3000 bp DNA marker (100 bp plus DNA ladder, Vivantis, Malaysia); Lanes 1-4, 6 and 7: Positive strains for $r f b E_{0157}$ gene at $259 \mathrm{bp}$. Lanes 5 and 8: negative samples. Lane 9: negative control. Lane 10: positive control.

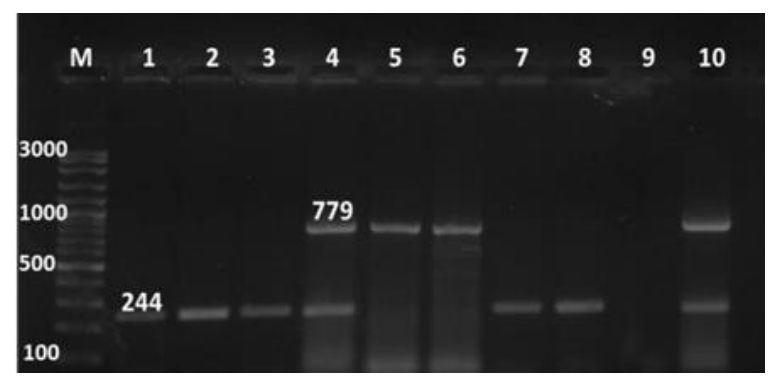

Fig. 3: Duplex PCR for detecting $s t x_{1}$ and $s t x_{2}$ genes in E. coli O157 strains. Lane M: 100-3000 bp DNA marker. Lanes 1-3, 7 and 8: Positive strains for $s t_{l}$ gene at $244 \mathrm{bp}$. Lane 4: Positive strain for $s t x_{1}$ and $s t x_{2}$ genes at 244 and 779 bp, respectively. Lanes 5 and 6: Positive strains for $s_{1} x_{2}$ gene at $779 \mathrm{bp}$. Lane 8: negative control. Lane 9: positive control.

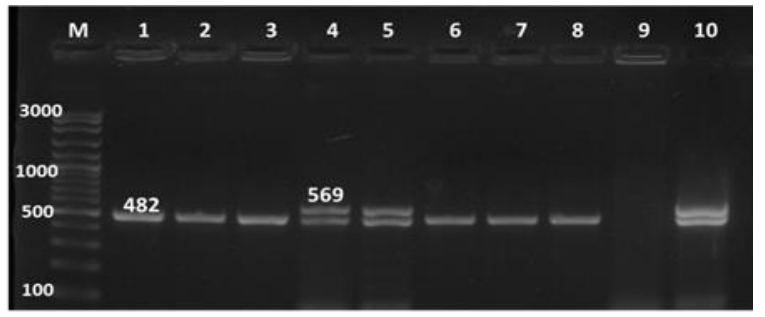

Fig. 2: Duplex PCR for detecting eae and ehylA genes in E. col O157 strains. Lane M: 100-3000 bp DNA marker. Lanes 1-3 and 68: Positive strains for eae gene at 482 bp. Lanes 4 and 5: Positive strains for eae and ehylA genes at 482 and 569 bp, respectively. Lane 9: negative control. Lane 10: positive control.

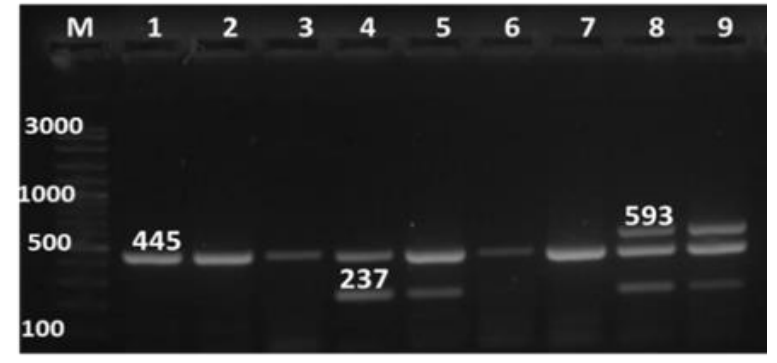

Fig. 4: Multiplex PCR for detecting blashv, blaтем and blaстхм genes in E. coli O157 strains. Lane M: 100-3000 bp DNA marker. Lanes 13, 6 and 7: Positive strains for blaTEM, gene at 445bp. Lanes 4 and 5: Positive strains for blasHV and blatem genes at 237 and $445 \mathrm{bp}$, respectively. Lanes 8 and 9: Positive strains for blashv, blaTEM, and blactхм genes at 237, 445 and 593bp, respectively.

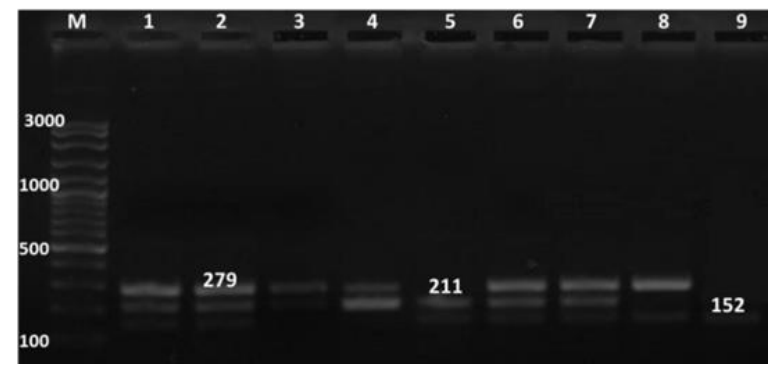

Fig. 5: Triplex PCR for detecting chuA, yjaA and TspE4.C2 genes in E. coli O157 strains. Lane M: 100-3000 bp DNA marker. Lanes 1, 2 , 6 and 7: Positive strains for TspE4.C2, yjaA and chuA genes at 152, 211 and 279 bp, respectively. Lanes 3 and 4: Positive strains for $y j a A$ and chuA genes at 211 and $279 \mathrm{bp}$, respectively. Lane 5: Positive strain for TspE4.C2 and yjaA genes at 152 and $211 \mathrm{bp}$, respectively. Lane 8: Positive strain for TspE4.C2 and chuA genes at 152 and 279 bp, respectively. Lane 9: Positive strain for TspE4.C2 gene at 152 bp.

Distribution of the virulence genes combination profile within $E$. coli $\mathrm{O} 157$ strains was demonstrated in Table (2). The predominant genes combination eae+stx were found in $66.7 \%$ of E. coli $\mathrm{O} 157$ strains, while only one $(6.7 \%)$ strain carried $e a e+s t x_{2}$ genes. Each of the genetic profiles of eae+stx + st $x_{2}+e h y l A$ and $e a e+s t x_{2}+e h l y A$ was detected in one $(6.7 \%)$ strain that regarded as a highly virulent combinations causing a severe pathological lesion (Possé et al. 2007). The presence of eae as a sole gene was detected in one strain (6.7\%) with the absence of other virulence genes. It is not surprising to identify a strain $(6.7 \%)$ that did not bear any of the AESTEC virulence genes, as Stenkamp-Strahm et al. (2017) recorded the lack of such genes in one E. coli $\mathrm{O} 157$ strain $(0.25 \%)$ recovered from calves. The existence of AE-STEC virulence genes on unstable mobile genetic elements leading to the loss of these genes during infection and strains that lost Shiga toxins were tightly linked to the other virulent Shiga toxins bearing strains based on multilocus sequence typing of these strains (Bielaszewska et al. 2007).

Regarding the antimicrobial resistance profile, all (100\%) E. coli O157 strains showed antibiotic multiple resistances (AMR) with variation to multiple antibiotic classes (Table, 3). A higher percentage of multi-resistances within bovine $E$. coli $\mathrm{O} 157$ was reported by Srinivasan et al. (2007) and Iweriebor et al. (2015), while Murinda et al. (2005) recorded that $80 \%$ of such strains were susceptible to all tested antibiotics. The emergence of multi-resistant bacteria has been linked to the pervasive veterinary antibiotic treatment in recent years (Saei et al. 2012; Mehmood et al. 2020).

The most resistance expression was detected toward amoxicillin/clavulanic acid, cefalexin, cefuroxime and tetracyclines at a percentage of $100 \%$ followed by $93.3 \%$ for sulfamethoxazole/trimethoprim, $80 \%$ for ampicillin and cefoxitin, and $66.7 \%$ for nalidixic acid and ciprofloxacin. 
Furthermore, the resistance to extended spectrum cephalosporins (ESC) was $60 \%$ for ceftriaxone and cefotaxime and $53.3 \%$ for cefquinome. The lowest resistance was detected toward gentamicin at a percentage of $40 \%$.

The antibiotic resistance profile revealed that $60 \%$ were ESC resistant E. coli, while the remaining strains (40\%) were ESC susceptible E. coli but resist to other non $\beta$-lactams. Variations in antibiotic resistance within $E$. coli O157 strains were detected by Mora et al. (2005), Srinivasan et al. (2007) and Hasan et al. (2019). The difference in resistance patterns may be attributable to the most prevalent types of veterinary antibiotics used in different geographical regions for treatment and prevention (Saei et al. 2012; El Jalil et al. 2020; Abd El-Fatah et al. 2020).

Detection of ESBLs encoding genes using multiplex PCR assay (Fig. 4) revealed the predominance of the bla $a_{T E M}$ gene in all $(100 \%)$ E. coli $\mathrm{O} 157$ strains, whereas the bla $a_{S H V}$ and bla $_{\text {СТХM }}$ genes were detected in percentages of $40 \%$ and $20 \%$, respectively (Table, 3). On the other hand, Iweriebor et al. (2015) in South Africa detected the absence of bla gene in E. coli $\mathrm{O} 157$ strains, while bla TEM $_{\text {and }}$ bla $_{\text {CTXM }}$ genes were detected in percentages of $27 \%$ and $65 \%$, respectively.

Regarding resistance genes profile as shown in Table (3), the bla TEM gene was found either alone (60\%) or in combination with bla $a_{S H V}$ and bla $a_{C T X M}$ genes. The bla $a_{S H V}$ gene was associated with bla while the combination of bla $a_{T E M}+b l a_{S H V}+b l a_{C T X M}$ was detected in ESC resistant strains only (20\%) and this illustrates the role of bla $_{\text {CTXM }}$ in resistance to ESC. Furthermore, all ESC resistant strains express resistance to most of the studied antibiotics classes. This is related to the horizontal transfer of plasmid mediated ESBLs encoding genes that contributes to the emergence of antibiotic resistance within E. coli strains (Terentjeva et al. 2019).

Molecular phylotyping of 15 E. coli O157 strains revealed an unexpected high percentage of B2 phylogroup within $80 \%$ of these strains, while each of B1, D and untypeable phylogroups were comprised one strain $(6.7 \%)$ as shown in Table (3). This disagreed with Tramuta et al. (2008) and Coura et al. (2017) who identified the predominant phylogroups within AE-STEC strains were B1 and A. The higher B2 level within E. coli strains indicates a serious concern, as the animals harboring $E$. coli strains with phylogroup B2 are a reservoir of a highly virulent extra-intestinal pathogenic strains that affecting humans (Clermont et al. 2000). In addition, identification of untypeable strain may be related to the recombination of two different phylogroups within the same strain as mentioned by Clermont et al. (2013). The relation between different phylogroups, antibiotic resistance and ESBLs genes characterization revealed that all ESBLs genes especially bla ${ }_{\text {CTXM }}$ bearing strains shared B2 phylogroup and multi-resistances. This association was determined by Lee et al. (2010) who stated that virulent resistant strains carrying the bla $a_{\text {Стхм }}$ gene are more prevalent in B2 phylogroup.

In conclusion, the present investigation revealed that diarrheic calves are a source of multi-resistant E. coli $\mathrm{O} 157$ that may transfer these resistance genes to other highly pathogenic strains, thereby limiting the treatment of such strains. Virulence genes profile has established that the correlation between Shiga toxins and Intimin has a crucial role in the pathogenesis of E. coli O157. Furthermore, the relation between ESC phenotypic resistance and ESBL genetic profiling confirmed the role of bla $_{\text {Стхм }}$ gene in ESC resistance. Finally, E. coli phylotyping showed a high prevalence of B2 phylogroup that related to highly virulent extra-intestinal strains.

\section{REFERENCES}

Abd El-Fatah SS, Saad AS, Salam AESAAE and Samir A, 2020. Study on dispersal of Escherichia coli and Salmonella enterica in retail beef and chicken meat. International Journal of Veterinary Science 9: 309-312. https://doi.org/ 10.37422/IJVS/20.023.

Bauer AW, Kirby WM, Sherris JC and Turk M, 1966. Antibiotic susceptibility testing by a standardized single disk method. American Journal of Clinical Pathology 45: 493-496.

Bielaszewska M, Köck R, Friedrich AW, Von Eiff C, Zimmerhackl LB, Karch H and Mellmann A, 2007. Shiga toxin-mediated hemolytic uremic syndrome: time to change the diagnostic paradigm?. PLoS One 2: e1024. https://doi.org/10.1371/journal.pone.0001024.

Bielaszewska M, Aldick T, Bauwens A and Karch H, 2014. Hemolysin of enterohemorrhagic Escherichia coli: structure, transport, and putative role in virulence. International Journal of Medical Microbiology 304: 521-529. https://doi.org/10.1016/j.ijmm.2014.05.005.

Boyd DA, Tyler S, Christianson S, McGeer A, Muller MP, Willey BM, Bryce E, Gardam M, Nordmann P and Mulvey MR, 2004. Complete nucleotide sequence of a 92-kilobase plasmid harboring the CTX-M-15 extended-spectrum betalactamase involved in an outbreak in long-term-care facilities in Toronto, Canada. Antimicrobial agents and Chemotherapy 48: 3758-3764. https://doi.org/10.1128/ AAC.48.10.3758-3764.2004.

CDC, 2020. Antimicrobial use and resistance (AUR) module. Centers for Disease Control and Prevention, Atlanta, GA https://www.cdc.gov/nhsn/pdfs/pscmanual/11 pscaurcurrent. pdf.

Chandra M, Cheng P, Rondeau G, Porwollik S and McClelland M, 2013. A single step multiplex PCR for identification of six diarrheagenic E. coli pathotypes and Salmonella. International Journal of Medical Microbiology 303: 210216. https://doi.org/10.1016/ j.ijmm.2013.02.013.

Clermont O, Bonacorsi S and Bingen E, 2000. Rapid and simple determination of the Escherichia coli phylogenetic group Applied and Environmental Microbiology 66: 4555-4558. https://doi.org/10.1128/AEM.66.10.4555-4558.2000.

Clermont O, Christenson JK, Denamur E and Gordon DM, 2013. The Clermont Escherichia coli phylo-typing method revisited: improvement of specificity and detection of new phylogroups. Environmental Microbiology Reports 5: 5865. https://doi.org/10.1111/1758-2229.12019.

CLSI, 2013. Performance standards for antimicrobial disk and dilution susceptibility tests for bacteria isolated from animals; second informational supplement. Document VET01-S2, Wayne, PA.

CLSI, 2020. Performance standards for antimicrobial susceptibility testing. 30th edition. CLSI supplement M100. Clinical and Laboratory Standards Institute, Wayne, PA.

Constable PD, 2004. Antimicrobial use in the treatment of calf diarrhea. Journal of Veterinary Internal Medicine 8:8-17. https://doi.org/10.1111/j.19391676.2004. tb00129.x

Coura FM, de Araújo Diniz S, Mussi JMS, Silva MX, Lage AP and Heinemann MB, 2017. Characterization of virulence factors and phylogenetic group determination of Escherichia coli isolated from diarrheic and non-diarrheic calves from Brazil. Folia Microbiologica 62: 139-144. https://doi.org/ 10.1007/ s12223-016-0480-9. 
El Jalil MH, Khamar M, Maaninou S, Dahha M, Zinedine A and Ameur N, 2020. Antibiotic resistance of Escherichia coli strains isolated from broiler meat in Morocco. International Journal of Veterinary Science 9: 305-308. https://doi.org/ 10.37422/IJVS/20.015.

Fagan PK, Hornitzky MA, Bettelheim KA and Djordjevic SP, 1999. Detection of Shiga-like toxin (stx1 and stx2), Intimin (eaeA), and Enterohemorrhagic Escherichia coli (EHEC) hemolysin (EHEC hlyA) genes in animal feces by multiplex PCR. Applied and Environmental Microbiology 65: 868872. https://doi.org/10.1128/AEM.65.2.868-872.1999.

Fang H, Lundberg C, Olsson-Liljequist B, Hedin G, Lindbäck E, Rosenberg A and Struwe J, 2004. Molecular epidemiological analysis of Escherichia coli isolates producing extendedspectrum $\beta$-lactamases for identification of nosocomial outbreaks in Stockholm, Sweden. Journal of Clinical Microbiology 42: 5917-5920. https://doi.org/10.1128/JCM. 42.12.5917-5920.2004.

Fang H, Ataker F, Hedin G and Dornbusch K, 2008. Molecular epidemiology of extended-spectrum $\beta$-lactamases among Escherichia coli isolates collected in a Swedish hospital and its associated health care facilities from 2001 to 2006. Journal of Clinical Microbiology 46: 707-712. https://doi.org/10.1128/JCM.01943-07.

Gannon VPJ, King RK, Kim JY and Thomas EJ, 1992. Rapid and sensitive method for detection of Shiga-like toxin producing Escherichia coli in ground beef using the polymerase chain reaction. Applied and Environmental Microbiology 58: 3809-3815.

Hasan MS, Hussein MA and Yousif AA, 2019. Confirmatory detection of Escherichia coli O157: H7 in diarrhoeic and non-diarrhoeic calves by using real time PCR with studying the antimicrobial susceptibility of these bacteria. Research Journal of Pharmacy and Technology 2: 245-250. https://doi.org/10.5958/0974-360X.2019.00046.5.

Hawkey PM and Jones AM, 2009. The changing epidemiology of resistance. Journal of Antimicrobial Chemotherapy 64 Suppl 1: i3-i10. https://doi.org/10.1093/jac/dkp256.

Iweriebor BC, Iwu CJ, Obi LC, Nwodo UU and Okoh AI, 2015. Multiple antibiotic resistances among Shiga toxin producing Escherichia coli $\mathrm{O} 157$ in feces of dairy cattle farms in Eastern Cape of South Africa. BMC Microbiology 15: 1-9. https://doi.org/10.1186/s12866 -015-0553-y.

Kamel M, El-Hassan DGA and El-Sayed A, 2015. Epidemiological studies on Escherichia coli O157: H7 in Egyptian sheep. Tropical Animal Health and Production 47: 1161-1167. https://doi.org/10.1007/s11250-015-0843-2.

Kang SJ, Ryu SJ, Chae JS, Eo SK, Woo GJ and Lee JH, 2004. Occurrence and characteristics of enterohemorrhagic Escherichia coli $\mathrm{O} 157$ in calves associated with diarrhoea. Veterinary Microbiology 98: 323-328. https://doi.org/ 10.1016/j.vetmic.2003.11.004.

Kuyucuoğlu Y, Şeker E, Sareyyüpoğlu B and Gürler Z, 2011. Detection of Enterohemolysin and Intimin genes in Escherichia coli $\mathrm{O} 157$ : $\mathrm{H} 7$ strains isolated from calves and cattle in Afyonkarahisar-Turkey. Kafkas Üniversitesi Veteriner Fakültesi Dergisi 17: 663-666. https://doi.org/ 10.9775/kvfd.2011.4577.

Lee S, Yu JK, Park K, Oh EJ, Kim SY and Park YJ, 2010. Phylogenetic groups and virulence factors in pathogenic and commensal strains of Escherichia coli and their association with blaCTX-M. Annals of Clinical and Laboratory Science 40: 361-367.

Mainil JG and Daube G, 2005. Verotoxigenic Escherichia coli from animals, humans and foods: who's who? Journal of Applied Microbiology 98: 1332-1344. https://doi.org/ 10.1111/j.1365-2672.2005.02653.x

Manna SK, Brahmane MP, Manna C, Batabyal K and Das R, 2006. Occurrence, virulence characteristics and antimicrobial resistance of Escherichia coli 0157 in slaughtered cattle and diarrhoeic calves in West Bengal, India. Letters in Applied Microbiology 43: 405-409. https://doi.org/10.1111/j.1472-765X.2006.01975.x

Mehmood K, Bilal RM and Zhang H, 2020. Study on the genotypic and phenotypic resistance of tetracycline antibiotic in Escherichia coli strains isolated from free ranging chickens of Anhui Province, China. Agrobiological Records 2: 63-68. https://doi.org/10.47278/ journal.abr/2020.014.

Mohsin M, Haque A, Ali A, Sarwar Y, Bashir S, Tariq A, Afzal A, Iftikhar T and Saeed MA, 2010. Effects of ampicillin, gentamicin, and cefotaxime on the release of Shigatoxins from Shigatoxin producing Escherichia coli isolated during a diarrhea episode in Faisalabad, Pakistan. Food borne Pathogens and Disease 7: 85-90. https://doi.org/10.1089/ fpd.2009.0311.

Monstein HJ, Östholm-Balkhed A, Nilsson MV, Nilsson M, Dornbusch K and Nilsson LE, 2007. Multiplex PCR amplification assay for the detection of blasHV, blaTEM, and

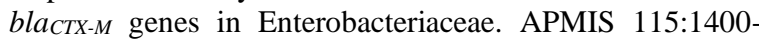
1408. https://doi.org/10.1111/j.1600-0463.2007.00722.x

Mora A, Blanco JE, Blanco M, Alonso MP, Dhabi G, Echeita A, González EA, Bernárdez MI and Blanco J, 2005. Antimicrobial resistance of Shigatoxin (verotoxin) producing Escherichia coli O157:H7 and non-O157 strains isolated from humans, cattle, sheep and food in Spain. Research in Microbiology 156: 793-806. https://doi.org/ 10.1016/j.resmic.2005.03.006.

Müller D, Greune L, Heusipp G, Karch H, Fruth A, Tschäpe H and Schmidt MA, 2007. Identification of unconventional intestinal pathogenic Escherichia coli isolates expressing intermediate virulence factor profiles by using a novel single-step multiplex PCR. Applied and Environmental Microbiology 73: 3380-3390. https://doi.org/10.1128/ AEM.02855-06.

Murinda SE, Ebner PD, Nguyen LT, Mathew AG and Oliver SP, 2005. Antimicrobial resistance and class 1 integrons in pathogenic Escherichia coli from dairy farms. Food borne Pathogens and Disease 2: 348-352. https://doi.org/10.1089/ fpd.2005.2.348.

Naylor SW, Roe AJ, Nart P, Spears K, Smith DG, Low JC and Gally DL, 2005. Escherichia coli O157: H7 forms attaching and effacing lesions at the terminal rectum of cattle and colonization requires the LEE4 operon. Microbiology 151: 2773-2781. https://doi.org/10.1099/mic.0.28060-0.

Paton AW and Paton JC, 1998. Detection and characterization of Shigatoxigenic Escherichia coli by using multiplex PCR assays for stxl, stx2, eaeA, enterohemorrhagic E. coli hlyA, $r f b O 111$, and $r f b O 157$. Journal of Clinical Microbiology 36: 598-602. https://doi.org/10.1128/JCM.36.2.598-602.1998.

Poirel L, Madec JY, Lupo A, Schink AK, Kieffer N, Nordmann P and Schwarz S, 2018. Antimicrobial resistance in Escherichia coli, in: Schwarz S, Shen J and Cavaco L (ed), Antimicrobial Resistance in Bacteria from Livestock and Companion Animals, American Society for Microbiology, Washington, USA, PP: 289-316. https://doi.org/10.1128/ 9781555819804.ch13.

Possé B, De Zutter L, Heyndrickx M and Herman L, 2007. Metabolic and genetic profiling of clinical O157 and nonO157 Shigatoxin producing Escherichia coli. Research in Microbiology, 158: 591-599. https://doi.org/10.1016/ j.resmic.2007.06.001.

Quinn PJ, Markey BK, Carter ME, Donnelly WJC and Leonard FC, 2002. Veterinary Microbiology and Microbial Disease. $2^{\text {nd }}$ Ed. Blackwell Science Ltd., UK.

Saeedi P, Yazdanparast M, Behzadi E, Salmanian AH, Mousavi SL, Nazarian S and Amani J, 2017. A review on strategies for decreasing E. coli O157: $\mathrm{H} 7$ risk in animals. Microbial Pathogenesis 103: 186-195. https://doi.org/10.1016/ j.micpath.2017.01.001. 
Int J Vet Sci, 2021, 10(1): 1-7.

Saei HD, Ahmadi E, Kazemnia A and Ahmadinia M, 2012. Molecular identification and antibiotic susceptibility patterns of Escherichia coli isolates from sheep faeces samples. Comparative Clinical Pathology 21:467-473. https://doi.org/10.1007/s00580-010-1134-y.

Srinivasan V, Nguyen LT, Headrick SI, Murinda SE and Oliver SP, 2007. Antimicrobial resistance patterns of Shigatoxinproducing Escherichia coli O157: $\mathrm{H} 7$ and O157: H7- from different origins. Microbial Drug Resistance 13: 44-51. https://doi.org/10.1089/mdr. 2006.9996.

Stenkamp-Strahm C, McConnel C, Hyatt DR, Magnuson R, Tenneson P and Linke L, 2017. Prevalence of Escherichia coli $\mathrm{O} 157$ shedding in preweaned calves on Colorado dairies. Journal of Food Protection 80: 990-993. https://doi.org/ 10.4315/0362-028X.JFP-16-531.

Terentjeva M, Streikiša M, Avsejenko J, Trofimova J, Koval̨enko K, Elferts D and Bērziñš A, 2019. Prevalence and antimicrobial resistance of Escherichia coli, Enterococcus spp. and the major food borne pathogens in calves in Latvia. Foodborne Pathogens and Disease 16: 35-41. https://doi.org/10.1089/fpd.2018.2523.
Thiry D, Saulmont M, Takaki S, De Rauw K, Duprez JN, Iguchi A, Piérard D and Mainil JG, 2017. Enteropathogenic Escherichia coli O80:H2 in Young Calves with Diarrhea, Belgium. Emerging Infectious Diseases 23: 2093-2095. https://doi.org/10.3201/eid2312. 170450.

Tramuta C, Robino P and Nebbia P, 2008. Phylogenetic background of attaching and effacing Escherichia coli isolates from animals. Veterinary Research Communications 32: 433-437. https://doi.org/10.1007/s11259-008-9042-1.

Vidal M, Kruger E, Durán C, Lagos R, Levine M, Prado V, Toro $\mathrm{C}$ and Vidal R, 2005. Multiplex PCR assay to identify simultaneously the six categories of diarrheagenic Escherichia coli associated with enteric infections. Journal of Clinical Microbiology 43: 5362-5365. https://doi.org/ 10.1128/JCM.43.10.5362-5365.2005.

Wang G, Clark CG and Rodgers FG, 2002. Detection in Escherichia coli of the genes encoding the major virulence factors, the genes defining the O157: H7 serotype, and components of the type 2 Shiga toxin family by multiplex PCR. Journal of Clinical Microbiology 40: 3613-3619. https://doi.org/10.1128/JCM.40.10.3613-3619.2002. 